\title{
Puebla: The Start of a Path Towards a More Audacious and Prophetic Theology in Latin America*
}

\author{
Víctor Martínez Morales, S. J. ${ }^{a}$
}

Pontifical Javeriana University, Bogotá, Colombia

http://orcid.org/0000-0003-0253-7234

RECEIVED: 20-11-19. ACCEPTED: 14-03-2020

Summary: 40 years ago, the Latin American bishops convened in Puebla to reflect upon and point towards new pastoral horizons and theological construction. This article conveys the dynamism, strength, and vigor of the message emanating from that meeting. Puebla gave clues of a new theology that, adhering to the Latin American method, can respond to the problems that question us with unprecedented vigor and invite us to envision new routes, fields of new approaches, and ways yet unpaved. The message arising from Puebla continues to be current. It opens up hope of new theological construction seeking to give a new dimension to its task, understand God's action in history differently, as well as the human condition and its relation to nature. We live in a plural context, broad and open to the construction of theologies able to offer new interpretations of God's revelation and action, a propitious moment to rethink theological efforts, regarding the challenges presented by Puebla. In this horizon, theological work should be understood from the experience of faith and fundamental openness of the being to God's creative and salvific action, in the gratuity of filiation in the Son and not as a mere intellective obligation of the Christian faith. Puebla presents, not only for the Latin American people, but for the church in general, a reflection in which we are constantly reminded that human beings can transform situations of injustice into opportunities for liberation, forgiveness and mercy. It is up to every Christian to undertake a path of trustful commitment, marked by a spirit of solidarity and responsibility towards his or her neighbour. In this way one can make known the face of God of whom Puebla speaks and who cries out for justice.

KeYwords: Commitment; hope; experience of faith; Puebla; pastoral work; theological effort.

\footnotetext{
${ }^{*}$ Reflection paper.

${ }^{a}$ Corresponding author. E-mail: vicmar@javeriana.edu.co. Current dean of the Faculty of Theology of the Pontifical Javeriana University. Member of the Didaskalia Research Group. Category A1 by Minciences.
} 


\title{
Puebla: el inicio de un camino hacia una teología más audaz y profética en América Latina y el Caribe
}

RESUMEN: Hace 40 ańos los obispos latinoamericanos se reunieron en Puebla, para reflexionar y señalar horizontes pastorales y de construcción teológica. En este artículo, mostramos el dinamismo, la fuerza y el vigor del mensaje emanado de aquel encuentro. Puebla dio pistas para una teología nueva que, fiel al método latinoamericano, puede dar respuesta a los problemas que nos interpelan hoy con fuerza inusitada y nos invitan a vislumbrar nuevos derroteros, campos de propuestas alternativas y caminos todavía intransitados. El mensaje de Puebla sigue siendo actual y nos abre a la esperanza en la construcción de una teología que busca redimensionar su quehacer, para comprender, de manera distinta, la acción de Dios en la historia, la condición humana y su relación con la naturaleza. Vivimos en un contexto plural, amplio y abierto a la construcción de teologías capaces de ofrecer nuevas interpretaciones de la revelación y la acción de Dios; un momento propicio para repensar la labor teológica, de cara a los desafíos presentados por Puebla. En este horizonte, el trabajo teológico debe entenderse desde la experiencia de fe y la apertura fundamental del ser humano a la acción creadora y salvífica de Dios, en la gratuidad de ser hijos en el Hijo y no como una mera obligación intelectiva de la fe cristiana. Puebla presenta, no sólo para el pueblo latinoamericano, sino para la iglesia en general, una reflexión en la que se nos recuerda constantemente que los seres humanos pueden transformar las situaciones de injusticia en oportunidades de liberación, perdón y misericordia. Corresponde a cada cristiano emprender un camino de compromiso confiado, marcado por un espíritu de solidaridad y responsabilidad hacia su prójimo. De esta manera se puede dar a conocer el rostro de Dios del que habla Puebla y que clama por la justicia.

Palabras Clave: Compromiso; esperanza; experiencia de fe; Puebla; pastoral; quehacer teológico.

\author{
How to CITE: \\ Martínez Morales, Víctor "Puebla: the start of a path towards a more audacious and prophet- \\ ic theology in Latin America”. Theologica Xaveriana (2021): 1-16. https://doi.org/10.11144/ \\ javeriana.tx71.psptapt
}




\section{Introduction}

A look at the concluding document of the III Latin American and Caribbean Episcopal Conference, which took place in Puebla in 1979, leads us to reconsider the event in light of of its meaning and current strength. This is evident when facing the challenges, horizons, and options that Puebla invites us to, as part of our theological tasks. In this measure, the proposal is to consider the approach by which Puebla revealed horizons that today should be the subject matter of theology, imperative projects and perspectives for current theological reflection, and theological themes not yet delved into nor approached with sufficient rigor.

Therefore, we set out to demonstrate the way theology has been consigned in the Puebla document. Its dynamism and strength continue to be valid, offering sufficient theological study resources. This effort calls for clearing new pathways, new proposals, and perhaps unexplored roads. In regard to being the bearers of the good news of the Gospel, we should make the affirmation "new wine in new wineskins" (Mt. 9:14-17; Mk. 2:21-22; Lk. 5: 33-39) a reality.

The Puebla document offers clues to a new theology that, while remaining loyal to the principles of the Latin American method, manages to answer the problems that presently interpellate with unusual force. As Pope Francis states, "the theologian complacent with his completed and finished thought comes through as mediocre" Therefore, we aim to respond to the present challenges with present-day responses. It is the only way to open up the future with hope. Because of Puebla's contribution, we have the responsibility to glimpse at and design theological knowledge capable of responding to our current reality and the changing times we are undergoing.

This way, going back to the legacy of what took place and was consigned in the Puebla document, present-day theology is invited to select useful topics and subjects of singular significance. Such is the contribution we can offer for theological reflection regarding the lives of the faithful; that is, from being who we are and having what we do effectively contribute to our continent's liberation.

\section{The Outlook, Enlightenment and Pastoral Praxis}

Let us begin with the following statement by Brazilian theologian and ecologist, Leonardo Boff (1938), in which he is referring to the unique organization of the Puebla document:

\footnotetext{
${ }^{1}$ Francisco, "Constitución apostólica Veritatis gaudium sobre las facultades y universidades eclesiásticas" 3 .
} 
Everything comes to light in the approach consecrated by Christian base community's practice and the continent's theological reflection inscribed in the Liberation Theology framework: observe analytically, judge theologically, and act pastorally. Firstly, the whole document initiates with a comprehensive critical analysis of the Latin American social reality detecting the main anxieties and hopes of our peoples. Theological reflection is constructed at this point to rethink in light of the faith the identified challenges in the examination. Conclusively, Christian practice guidelines are laid out, imperative to the analysis and reflection on effective action in link with reality. ${ }^{2}$

Indeed, as a document, Puebla is the arrival point of prolonged work, prayer, and discernment in the entire Latin American and Caribbean Church. It has been considered the highest effort of ecclesial participation where the episcopal conference is but a moment of this total participative process. Hence, Puebla is seen more as an ecclesial event rather than a continent's episcopal assembly³.

The diagnostics on the Latin American and Caribbean reality elaborated in Puebla is not the result of scientific work nor measurements upon the population but the fruit of pastoral experiences. From that arises its richness and strength. Christ's faces in Latin America (nos. 31-39 of document) are of those who suffer, the tangible underprivileged and victims of the continent's economic, political, and cultural systems.

Puebla founds itself on the outlook upon the reality of our peoples, their oppressive and destitute situation. These result from exploitation and pauperizing mechanisms, relations of inequality and exclusion, the presence of unbalanced structures between the hub and the peripheries, where the elite monopolize power, wealth, and knowledge before a people that lack the basic needs to guarantee their livelihood.

Reality comes to light from the standpoint of the Word, pontifical magisterium, and ecclesial documents. As to our people's desire for an integral liberation ${ }^{4}$, the following question is answered: what are the paths of liberation that God makes known?5. The answer is Jesus Christ. That being said, "Christ Liberator should be explicitly announced"6. Though the document embodies conservative Christology,

\footnotetext{
2 Boff, "Lectura del documento de Puebla desde América Latina oprimida", 57-58.

3 "The Puebla document [...] was not only the product of a brief episcopal assembly but also the efforts of believers (thinking and prayerful) of the whole Church of a continent. In many countries and dioceses, an opportunity was given to all to collaborate from the simple Catholic of Sunday Mass (able to answer several surveys) to the simple suggestions of poor and distant communities, to the most specialized and technical contributions of movements, parishes, dioceses and national episcopal conferences", 84).

${ }^{4}$ Celam, "Documento conclusivo de Puebla" 5.4.,

${ }^{5}$ Ibíd. 163.

${ }^{6}$ Ibíd. 1032.
} 
there is a constant watch for this bright horizon in Puebla, Which was illuminated by the Second Vatican Council, the Evangelii nuntiandi exhortation, and the Medellin Document to lead to this finding, in Puebla:

The image of a Jesus Christ, Liberator, whose option was for the poor, announcing and making God's Kingdom a reality through his liberating practices as God's total and global liberation, and thereon. Such is authentic Christology that supports the Latin American Church's great options committed to its peoples' integral liberation. ${ }^{7}$

The third movement is practical-pastoral work; the most apt means for evangelical action. That is the option for goals and means that lead to the Church's mission. Puebla projects itself as an evangelization action of the culture to serve and liberate our people, encompassing a call and a broad range of tasks. An analytical look on reality (observing), theological enlightenment (judging), and pastoral action (taking action) are the approach that leads to the depth and experience of faith that comes from reality8.

Without a doubt, this methodological contribution is of profound significance for theology. The method followed and consigned in Puebla positioned itself not only in Latin American theological work but also contributed to world theology. The springboard of theology ought to be reality, current situations, and perplexing events arising from the issues that concern us should be the springboard.

Theology must be accurate in pointing out the causes and ways to eradicate new forms of slavery, poverty, violence, and suffering of a significant part of our peoples. Theology cannot be indifferent to either misery or anguish. Instead, it must give direction to reflection, production, and teaching to favor victims of human iniquity.

\section{The Church in Puebla: God's People}

For some authors, the Third CELAM Conference in Puebla was a meditation on the Latin American Church. It deals with the legacy derived from the Second Vatican Council, whose strength of insertion in the modern world was reflected in Medellin a decade before. The Second Vatican Council had underscored and introduction of the Church as the people of God, conformed by men and women living in commu-

\footnotetext{
${ }^{7}$ González y Ruiz, Puebla. El hecho histórico y la significación teológica, 65.

8 "The Puebla Document is structured based on the traditional method of seeing, judging, and taking action (elaborated and popularized by the Catholic Working Youth of Belgium). The second part occupies the key position of judging that procures the step from seeing to taking action. Aforesaid was the meaning of what we called the double theme of identity, the articulating nucleus of the Puebla document" (Alessandri, "Puebla y sus repercusiones", 97).
} 
nity, encouraged by God Himself, and are the seed and hope of the Kingdom'. In emphasizing the Church as the people of God, the Church reestablishes the dignity of the laity. We are all members of the Church; all, women and men; all belonging to the people, hierarchy, and laity; a priestly people in its entirety.

The Latin American post-conciliar ecclesial experience distinguishes two stages, the social dimension deriving from the apostolic movements of religious and priestly bodies and the active laity. It regards the committed elite, owned by the urban middle class. This movement focuses on small action and militant groups. Therefore, small communities, ferment of the Christian people, benefit from the change in social structures, and consciously act upon all injustice; communities seeking liberation as a united response concerning the poor. Medellin clearly expresses this stage.

The second division turns to the Latin American people aiming to listen to their voices and outcries. In that respect, the main interest is placed upon popular pastoral work since it revalues popular religiosity and stresses on the small community.

The popular supporting classes incarnate the Church giving birth to ecclesial base communities and popular liberating pastoral work. The Church's relationship with civil society is the inauguration of a new model: a direct connection without the mediation of State or governing classes. The Church directly inserts itself within the popular classes desiring to be more than just a church for the people. It wishes to be a Church with and of the people; a Church borne of the faith of those oppressed. ${ }^{10}$

The strength and identity that ecclesial base communities are gradually acquiring are consequential to that ecclesial notion. "It is not unusual that, in the conference, the idea of Church as the people of God, occupy a privileged place" ${ }^{11}$.

Now if Medellin explicitly stressed the Church being a community, Puebla addressed itself to the Church as a people of God encompassing base communities ${ }^{12}$. On the one hand, that is, including communities centered on the Word, experience,

\footnotetext{
${ }^{9}$ Concilio Vaticano II, "Constitución dogmática sobre la Iglesia Lumen gentium" 9.

${ }^{10}$ Boff, "Lectura del documento de Puebla", 55.

${ }^{11}$ Quarracino, "Historia y fases principales de la nueva conciencia eclesiológica en América latina: Vaticano II-Medellín-Puebla”, 32.

${ }^{12}$ Ecclesial base communities create a greater personal inter-relationship, acceptance of God's Word, an examination of life, and reflection upon reality. In light of the Gospel, commitment to family, work, neighborhood, and the local community becomes stronger. We happily report an increasing number of small communities as our own important ecclesial fact and hope for the Church. The aforesaid is mostly noticeable in the peripheries of large cities and rural areas which prove ideal environments for the surge of new laity services where family catechism and adult faith instruction has been imparted in simpler and more adequate ways. (Celam, "Documento de Puebla" 629).
} 
and sacramental celebration and, on the other, their commitment to human promotion and justice, to contributing to the construction of God's Kingdom.

We cannot overlook those who considered these communities a deviation from the true meaning of community or, even more so, the hypertrophy and marring of it. In that measure, they were a "popular Church," constituted from "below," uneducated as to the magisterium and hierarchy. Suppose such reality in some communities' praxis is undeniable. The persecution and annihilation of ecclesial base communities ${ }^{13}$ in the entire Latin American and Caribbean continent albeit some have survived, are equally undeniable.

Assessing the Church as the people of God derives from an important, threefold set of themes: popular religiosity, culture, and history. As for popular religiosity, the presence of the continent's poor Latin American Christian people made its value resurface," as also "the issue of its existence, originality, and restoration of its values" ${ }^{14}$. Nonetheless, popular religiosity acquired its highest degree of understanding, assessment, and legitimacy concerning history and culture, demanding a higher degree of awareness. "Puebla, in its ecclesiological development, considers the Church as a People of God. People, culture, and popular religiosity are topics intimately connected"15.

Considering popular religiosity, history, and culture allows for making distinctions, as well as forming and clarifing theological reflection in its depth and intention regarding elements like religion, religiosity, devotion and piety. To those, add popular religion, religiosity, and piety. At this point, it is convenient to warn different options should be had when wedging in concepts, provided the wording configures realities.

Since our people are the recipients and subject of our theological work, the real issues, contact with, experience and nearness to the people is a reality of the concrete incarnation. That reality makes us opt for a mode to make theology based on reality, its actual situation, events, and issues.

Presently, it is necessary to remember that we must, first of all, start from life, history, and reality, not from its projection or undertakings. Second, to go beyond our comfort zones to assume ambiguous realities whose different shades are annoying

\footnotetext{
13 "An ascertainment made by Pueblo, almost lightly, explains why there are misgivings or repression on behalf of our countries' dominant forces concerning them. The poor, also encouraged by the Church, have begun to consolidate to live out their faith and claim their rights. The Church's prophetic decry and its concrete commitments in regards to the underprivileged have wrought at times, persecution upon themselves [...] of diverse kinds and the destitute have themselves been victims. (Perdía, "Factores generales que determinan hoy la nueva conciencia de la Iglesia latinoamericana”, 44).

${ }^{14}$ Quarracino "Historia de la nueva conciencia eclesiológica”, 33.

${ }^{15}$ Ibíd., 35.
} 
and threatening. The option is love, the generator of life, loyal love, and the meaning and strength of relating to one another. We must go beyond the gospel doctrine, from religion to faith, to question: "Where do the poor pray? What is the religion of the deprived? What do the underprivileged celebrate? [...]. This religious hue gives a new tonality to the theological reflection of Latin America" ${ }^{16}$.

\section{Integral Liberation, a necessary balance}

Two underscoring points mark a double tendency in the Latin American Church. The first underlines the mission of the Church as something primarily religious, its stress on the spiritual and interest in the formation of a good Christian. Consequently, conversion leads to a change in structures and commitment—-the second, assuming integral salvation as the Church's mission underlines how the whole process should develop from the poor. Working towards a new way of living together should be considered politically, socio-historically, and culturally.

Two clear designed tendencies in the continent with two diverse pastoral practices and their respective theologies are: one continuous, and one innovative [...] Both these tendencies keep the Latin American Church in tension as clearly proven to Puebla in the preparatory phase. The continuing tendency is to attempt making Puebla a discerning assembly of correction and rectification of Medellin's “erred interpretation." Mostly, [as to] the preferential option for the poor, the integral liberation, base ecclesial communities, understood as a Church born of the people by the Holy Spirit. The innovative tendency is to confirm and give consistency to Medellin's better options, establish a new type of direct relationship between the Church and civil society, in an alliance of participation and liberty with the lower social class divested of participation and liberty. ${ }^{17}$

As a refult, there were many concerns, misgivings, warnings, and lack of trust reached Puebla. Additionally, their centering of Jesus' persona in their presence, attitudes, interventions, and profound, meaningful statements is clear in their commitment towards the most underprivileged. In an evangelizing Church in favor of Human rights and social justice, the desire for the favoring option of an integral liberation is evident. Accordingly, during the conference, an equally distant and balanced position between the two tendencies made possible the creation of a propitiously peaceful and serene atmosphere radiating the continent's ecclesial life.

\footnotetext{
${ }^{16}$ Hurtado, "La religión del pueblo en América Latina”, 199.

${ }^{17}$ Boff, "Lectura del documento de Puebla", 57-58.
} 


\section{A Prophetic Clamor}

The Latin American and Caribbean Church verifies its prophetic action by its dynamics in decrying all sins of injustice, oppression, and repression in the different sites of the continent, where torture, the number of the missing, and the doctrine of national security had become the State's policy. Ten years following Medellin, the clamor was evident: "Medellin was now pointing towards [...] the proof of this fact: 'a hollow clamor erupts from millions of men, asking their pastors for liberation that comes from nowhere.' It might have then been a silent one, but now it is clear, increasing, and threatening ${ }^{18}$.

That was undoubtedly a prophetic attitude of commitment and struggle, verified by the favored option for the poor and the defense of Human Rights. A fight in which unmasking all social sin was to become the nodal part of all Christians' mission.

Prophetism from the standpoint of parrhesia and conversion opens ways towards hope and liberation. In sequence to Medellin, Puebla undeniably echoes this centered reality on the announcement of the Gospel. The sense of it is a turning over to the persona of Jesus Christ in His announcement of the Good news, bearer of life in abundance.

Thus, for Puebla, the prophetic Church is the evangelizing Church, the Church of the poor, and the liberating Church. That is, it is dealing with a creative Church that clears ways towards the source itself of the Gospel to denounce all idolatry and ideology against God and man. Puebla placed in evidence that the Latin American people are not only poor and oppressed but at the same time believing and possessing a strength of hope and liberation.

At this time, our theological task of commitment towards promoting justice encouraged by the prophets' radical and decisive actions and proceedings should not diminish. The critical role of theology should be maintained. It is real prophetic power in its denouncement and announcement dynamics, hinting at options that construct new realities and possibilities, offering and setting free change and transformation processes.

Today, particularly in Latin America, particularly in Colombia, the struggle for justice and the defense of Human Rights has cost the disappearance and death of numerous social and environmental leaders, defenders of life and dignity. They are the prophetic voice of our time.

${ }^{18}$ Celam, "Documento de Puebla” 89. 


\section{The Poor, Always a Preferential Option}

Puebla confirms the option proposed in Medellin: "We declare that there is a need in all the Church for conversion in opting for the poor with an outlook on their integral liberation" ${ }^{19}$. Considering that:

Favoring the poor to announce the Gospel in an all-inclusive language in contrast to a particularity or preference, may be very annoying to many. From that stance, the Gospel seems harsh and demanding to the privileged in an unjust social order. Exclusivity would sideline them implied in this announcement seen as an outcry against all that strips and oppresses the poor. ${ }^{20}$

Poverty reaching total destitution in the first decade of the current century has proven worse to an overwhelming majority ${ }^{21}$. Puebla confronts us beyond recorded figures with real faces belonging to the indigenous, peasant, working, and marginalized brothers and sisters. To this respect, it is worthwhile mentioning that in their midst, it is the women in the different social sectors doubly exploited, marginalized, and oppressed.

For that matter, evangelization must start with a genuine commitment to the poor, taking a stand against injustice's prevailing oppressive mechanisms. In claiming rights and dignity, it is imperative to work for the people's organization, awareness, leadership and action ${ }^{22}$. This should happen with unfailing faithfulness even during times of persecution and vexation of which the poor, men and women of the Church alike, have been made victims ${ }^{23}$.

Presently, more than ever, our theological task must favor the poor, the vulnerable, and the crucified, in the clear option for the promotion of the faith and the struggle for justice ${ }^{24}$. Theology needs to be flawless in pointing out the causes and approaches in eradicating new forms of slavery, poverty, violence, and suffering in most of our peoples. Theology cannot be indifferent to misery nor anguish every

\footnotetext{
${ }^{19}$ Ibíd. 1134.

${ }^{20}$ Gutiérrez, "Pobres y liberación en Puebla”, 42.

${ }^{21}$ See Celam, "Documento de Puebla" 1135.

22 "Puebla's Church does not speak to the poor using words of resignation or patience, begging, or charity; instead, in terms of liberation. The Church desires to be at the service of concrete movements and works by which the poor themselves fight for their liberation. She does not propose to take their place but rather, to awaken and train them to be the artifice of their liberation." (Comblin, "La conferencia episcopal de Puebla", 96).

${ }^{23}$ See Celam, "Documento de Puebla" 1138.

${ }^{24}$ The numbers of Puebla in which the faces of the poor of that time appear are well known. The question we ask now is what are the faces of the poor and crucified of our time?
} 
time it is obliged to orientate its reflection, production, and teaching in favor of the victims of human iniquity.

It is the theological task to consider, also, the poor in spirit, which implies becoming in charge of its evangelizing action and strength, throughout history. Also, it is obedience to the Spirit and being led by Him. In this measure, we must deepen in meaning and fecundity of its action, the community's fabric and formation, the making of the Word's life and celebration.

Therefore, it is vital to explicit and work on the meaning of the notion of the poor with spirit, meaning that those who lack a livelihood live because of their obedience to the impulse of the Spirit. In the same way, we must approach those among the poor in spirit that make clear their relation to God. The way they place themselves in His hands justifies their living and sharing in peace together in poverty.

\section{The Youth, An Ever Present Option}

Young people have a preferential place in the Latin American episcopate: "Latin American youth are not considered abstract. There is a diversity of young people distinguished by their social situation and socio-political experiences in their respective countries" ${ }^{25}$. The youth both need to be evangelized and carry out the vocation to evangelize. Favoring the youth in Puebla implies their integral liberation and search for communion and participation in the Church ${ }^{26}$.

In response to the spirit's call to center on Jesus' persona is the search for faithfulness and an authentic life experience of Christianity. Of youth is the inquiring attitude of non-conformity, endless questions about goings-on ${ }^{27}$. They seek originality, authenticity, and what is their own. Questions on meaning, on the one hand, induces exposure of falsehoods, incoherencies, and untruths. On the other, they identify what is essential and primordial: "Puebla is aware that a great part of them actively live their faith and so, are the Church called to take part in the evangelization that she proposes" ${ }^{28}$.

Puebla's option for the youth infers a call for the new generations to layout new roads of liberation with passion. From the young face of Christ, to glimpses into processes that make possible the faithful practice of Christianism in the continent. Puebla also reveals the youth's proactivity in constructing the Church and their role in evangelization. That is, ecclesial and evangelizing processes are agents. Our theo-

\footnotetext{
${ }^{25}$ See Celam, "Documento de Puebla” 1175.

${ }^{26}$ Ibíd. 1166.

${ }^{27}$ Ibíd. 1167.

${ }^{28}$ Gutiérrez y Córdoba, “La opción por los jóvenes”, 312.
} 
logical work cannot overlook our Latin American youth's walkthrough nor critical questioning, and non-conformist attitude in seeking that make them revolutionary and propositive, capable of significantly contributing to history.

The eyes of the youth are brimming with hope; they can offer all that is favorable to building a better future. With this in mind, our theological task encourages the journey in that direction: towards the future. It encourages them to follow Jesus persistently with renewed passion. To this measure, we trustingly expect a new birth that will make us tread the journey that transforms us into pilgrims of hope.

\section{Conclusion}

The Puebla document, a product of the Third Latin American and Caribbean Episcopal Conference, is not just a document. Instead, it is the main event without which the Latin American Church's history would be difficult to understand. Only with the insights and discussions generated in Puebla can articulate the previous and later conferences, particularly Medellin and Aparecida (2007).

Puebla invites us to be mindful of our current theological task whose demands we carry out in link with reality, precise conjunctions, and from the perspective and surroundings of today's destitute, victims, and neediest. Any theology's focal point should be anthropological; a comprehensive and integral reading that puts any scientificist, statistical, or socio-logistic reductionism in check. Far from inner fragmentations in our theological task, we procure dialogue with other sources of knowledge and disciplines that allow us to reach truth regarding Christ, the Church, and the being.

Forty years after the Puebla Conference, we may affirm that it has been accepted with satisfaction and by many with real pleasure and relief. Its historical importance is undeniable. Notably, it tends to make the message from Medellin extensive to the Church's evangelizing mission. We cannot say for sure that everything in Puebla was perfect, for there were lights and shadows. "Several individuals had agitated the phantom of a parallel Puebla. There was no such parallel Puebla. Practically all known Latin American theologians were present in Puebla, extramural, in particular, the best representatives of the liberation theology" 29 .

It is not worthwhile to go through conspiracy movements particularly or in regards to a parallel Puebla or whether whatever written was in fact stated, since they may become challenging to our continent's Church's men and women, and theolo-

\footnotetext{
${ }^{29}$ Comblin, "La Conferencia episcopal de Puebla", 277.
} 
gians of either gender. Conversely, it is convenient to underline intuitions and bets that continue to be verifiable.

As with Medellin, Puebla outlined continental ecclesial and theological tasks. It introduced the theology of communion and participation to the unconscious level making us more sensitive towards exclusion, marginalization, inequality, becoming vulnerable, and injustice. The list of faces has increased compared to that of Puebla: youth, women, the poor, afros, natives, migrants, the displaced, the homeless, social and environmental leaders (male and female), people living with HIV, in prostitutes, victims of violence. Alongside them are the animal species that have been affected by life and made vulnerable at risk of extinction, suffering human mistreatment; our planet increasingly challenged in its capacity of resilience; our shared habitat transformed into a vast waste deposit, as stated by Pope Francis ${ }^{30}$.

Puebla positions the approach of our theological tasks. They conceive a theology from the roots, from reality as a historical practice of liberation. How do we bring to date the passion for the Gospel in these times of post humanisms, of comfort, and intercultural societies? Theology is closely related to history; Christology to concrete faces, the Church to society; the Gospel to culture, the Kingdom's values, and human rights. The observing, judging, and taking action approach allows us to become aware that there is still much to do though we have made strides.

As to our theological work, the Third CELAM Conference has blueprinted the course of depth, investigation, and progress for the continent particularly in theological issues. In continuity with Medellin, albeit causing rupture with a traditional theology anchored in Christianity based on liberation theology, Puebla casts new models and searches for commitment and transformation of the continent's ecclesial life.

To go 40 years back to Puebla means to update points needing to be specified, interwoven fabric adjustments, and tasks demanding reconsideration. However, as women and men theologians, Puebla's retrace requires a look at the task at hand, unresolved problems, and pending work. Mainly, it implies a look at the challenges not yet assumed, formulating of proposals and options, and the taking of actions.

New realities demand new theological works. A few realities that make up new foci of interest and theological reflection are: current ecological emergencies, the limits to genetic therapy, the digital gap, nanotechnologies, increasing social inequalities, immigration; also, catastrophic consequences of the economic market; the crisis of the National State, religious pluralism and new technological and media culture.

\footnotetext{
${ }^{30}$ Francisco, "Carta encíclica Laudato si' sobre el cuidado de la casa común” 21.
} 
On one hand, discernment is essential in both enlightenment and judgment. On the other, a true prayerful, mystical, and contemplative life of prayer that brings us down to our knees before God. From a live and incarnate faith, conscious and consistent, nourished by a prayer of familiarity with the Creator, we can perceive the path to follow.

Open to the mystery and pulled by God's magis and Truth, with a passion for the wisdom that springs from revelation, women and men theologians are called to remain in the fields. Seeking and growing; permanently interweaving knowledge and belief, because Truth is an intricate tapestry of different interpretations, open and developing. From the kerygma's core itself, the Gospel of Jesus incarnates in ecclesial and human life, starting from the mystery encamped in the Trinity becoming the Church, the leaven for universal fraternity.

Action is a product from the heart of the Gospel, the dynamics of which go back to reality, recreate, change, and consequently transform. The Gospel calls us to the liberating action of broad participation and integration and profound innovation and creativity. This action is reflected in the evangelization of cultures and the enculturation of the Gospel. the dynamics of practice itself that going back to reality, recreate, change, and consequently transform. It is the liberating action of broad participation and integration and profound innovation and creativity. This action verifies the evangelization of the cultures and the enculturation of the Gospel.

Questioned by the new evangelization about practical-pastoral work, requires that we be creative and discover new forms of reflecting upon, producing, and teaching theology. It demands new meaningful routes to encourage the transformation of our society, our ecclesial communities, and our university institutions.

Theological work today is closely related to other disciplines. Theologians thus are pressured to heighten dialogue with other sciences and with each other ${ }^{31}$. Interdisciplinarity, multidisciplinarity, and transdisciplinary are seen as strategies or means that clarify and empower theological proposals. There is no reason why theology should fear complexity. The relation with other fields of knowledge is imperative. Even more so when it comes to teaching the sciences, specifically, theology shall remain an ever valid assignment.

In the future, the theological task must be the fruition of dialogue between cultures and religious traditions. Interculturality, great synergy, and interchange shall guide theological reflection in an increasingly uniform and intercommunicated world. A few theological issues shall also be enlightened, without a doubt in dialogues with

${ }^{31}$ Francisco, "Veritatis gaudium" 4c. 
the Christian ecumenical community. Thus, openness to conversations at different levels and with different interlocutors is necessary. Ultimately, according to new technical paradigms and communication, it is in creating networks, establishing new ways of being connected and achieving new approaches to interaction that will lead us to forge bonds with academic institutions and par centers dedicated to theological reflection in the different global latitudes ${ }^{32}$.

\section{References}

Alessandri, Hernán. "El futuro de Puebla y sus repercusiones en la iglesia y en la sociedad latinoamericanas". En Puebla. El hecho histórico y la significación teológica, editado por Olegario González de Cardedal y Juan Luis Ruiz de la Peña, 83-149. Salamanca: Sígueme, 1981.

Boff, Leonardo "Lectura del documento de Puebla desde América latina oprimida". En Puebla. El hecho histórico y la significación teológica, editado por Olegario González de Cardedal y Juan Luis Ruiz de la Peña, 50-82. Salamanca: Sígueme, 1981.

Celam, "Documento conclusivo de Puebla". Celam, https://www.celam.org/documentos/ Documento Conclusivo Puebla.pdf(consultado el 02 de agosto de 2020).

Comblin, Joseph. "La conferencia episcopal de Puebla”. Mensaje, 277 (1979): 117-123.

Concilio Vaticano II, "Constitución dogmática sobre la Iglesia Lumen gentium". Vatican, http://www.vatican.va/archive/hist councils/ii vatican council/ documents/vat-ii const 19641121 lumen-gentium sp.html (consultado el 02 de agosto de 2020).

Francisco, "Carta encíclica Laudato si" sobre el cuidado de la casa común". Vatican, http://www.vatican.va/content/francesco/es/encyclicals/documents/papa-francesco 20150524 enciclica-laudato-si.html (consultado el 02 agosto de 2020). . "Constitución apostólica Veritatis gaudium sobre las facultades y universidades eclesiásticas”. Vatican, http://www.vatican.va/content/francesco/es/ apost constitutions/documents/papa-francesco costituzione-ap 20171208 veritatis-gaudium.html (consultado el 02 de agosto de 2020).

González de Cardedal Olegario y Juan Luis de la Peña, Puebla. El hecho histórico y la significación teológica. Salamanca: Sígueme, 1981.

${ }^{32}$ Ibíd. $4 \mathrm{~d}$. 
Gutiérrez, Gustavo. "Pobres y liberación en Puebla". Diakonia 10 (1979): 39-69.

Gutiérrez, Mario y Juan Vicente Córdoba. "La opción por los jóvenes” En Análisis de Puebla, editado por Alberto Múnera, 309-313. Profesores 10. Bogotá: Universidad Javeriana.

Hurtado, Manuel. "La religión del pueblo en América Latina”. Razón y fe, 1438 (2019): 197-209.

Perdía, Mateo. "Factores generales que determinan hoy la nueva conciencia de la iglesia latinoamericana”. En Puebla. El hecho histórico y la significación teológica, editado por Olegario González de Cardedal y Juan Luis Ruiz de la Peña, 36-49. Salamanca: Sígueme, 1981.

Quarracino, Antonio. "Historia y fases principales de la nueva conciencia eclesiológica en América latina: Vaticano II-Medellín-Puebla”. En Puebla. El hecho histórico y la significación teológica, editado por Olegario González de Cardedal y Juan Luis Ruiz de la Peña, 15-35. Salamanca: Sígueme, 1981. 